\title{
Chemical Composition and Modeling of the Functions of Termitarium
}

\author{
Kamalu, C. I. O. And Okolie, I. J. \\ Chemical Engineering Department Federal University of Technology, P.M.B. 1526, Owerri, Nigeria
}

\begin{abstract}
The work was carried out in Fugro Consultants Nigeria Limited, Port Harcourt. It was the identification, extraction and characterization of chemical compounds responsible for making termination. The results showed that termitarium contains $11.6(\mathrm{~g} / \mathrm{kg})$ of TOM; $15.9(\mathrm{mg} / \mathrm{kg})$ of Magnesium, $11690(\mathrm{mg} / \mathrm{kg})$ of iron and $23.3(\mathrm{mg} / \mathrm{kg})$ of extractable chloride which are responsible for structural stability of termitarium. The result also revealed that increase of clay content enhances the structural stability of termitarium. \% water absorbed Vs time(s) for control and termitarium, mean number of seedings Vs time (days) for control and termitarium, gave their R-square (correlation coefficient) as 0.9975, 0.9951, 0.9959, 09807 and 0.09995 respectively.
\end{abstract}

Keywords: Chemical composition, termite, termitarium, biomodeling, curve-fit, nest, castes.

\section{Introduction}

Termites are polymorphic social insects that live in nests known as Termitaria [1]. The function of termitarium is to house and protect the colony, store food and maintain optimum environment. They constitute a nuisance to agricultural farms because of the space occupied and veracious nature of the termites [2]. The termitaria are built of soil and earth particles which are cemented together to form hard bricklike material which are very resistant to weathering and very difficult to chip with a sharp pick. A study on termitaria carried out by Adepegba and Adegoke, [3] confirmed that termites do actually stabilize the soil before use. An extract of the brown acidic substance of soldier termite (petroleum ether) was analyzed and this showed that the organic substance was a mixture of acetic 2 - amino glucose and protein, both being hydrolysis products of chitin and proctodael matter. This substance supports cementations and similar to the acetic secretion of solider termites.

The objective of this study is to determine the chemical composition of termitarium and to ascertain the chemical compounds responsible for structural stability of the termitarium by comparing the amount of chemicals found in termitarium to that of clay soil (control).

This work involves only the identification, extraction and characterization of chemical compounds in termitarium, and modeling of some of the activities in the construction of termitarium.

\section{Modification of Clay by Termites}

Soil particles probably undergo modification through the gut because of the extremely alkaline $\mathrm{pH}$, reaching values up to $12[1,12]$.

However, although the role of an alkaline environment in the termite gut is still unclear, there is strong evidence that the high $\mathrm{pH}$ is related to $\mathrm{K}$ transport. Micas from vermiculite by weathering, releases $\mathrm{K}^{+}$and replaces other exchangeable cations mainly $\mathrm{Ca}^{2+}$ and $\mathrm{Mg}^{2+}[9,13]$. Following this reason, it could be speculated that clay minerals rich in $\mathrm{K}^{+}$would be modified during the construction of termite moulds because of $\mathrm{K}^{+}$ extraction by a biological metabolism of soil-feeding termites by which free charges would be neutralized with cations from organic matter such as $\mathrm{A} 1^{3+}$.

Stabilization, can notify the properties of soils to control their shrinkage and swelling characteristics and so improve the binding ability of the clay in the soil [14].

The compaction activities carried out by termites increase the soil density and hence its strength and resistance to mechanical damage during ant hill building. It also reduces water absorption but with associated reduction in porosity, durability may be reduced. Effectiveness of compaction depends on the pressure, arrangement, soil type and water content.

Fibres are widely used by termites when building with clay. They act to increase the tensile strength, reduce density, accelerate drying and reduce cracking by dispersing stresses.

Straw fibres vary in shape, sizes strength elasticity and their bond strength with clay soil. Other suitable vegetable fibres include hay, hemp, millet, sisal and elephant grass. Cow, horse and camel dung are also used as additives by termites because they contain short fibres which make the soil workable for plastering and rendering [15] 


\section{Physio-Chemical Properties}

The exchange of cations and anions between the solid and liquid phase in oxic horizons and in the overlying top soils is mainly conditioned by type and amount of clay minerals, oxides and organic matter. Since oxic horizons are generally low in silt, the contribution of this particle size fraction to exchange reaction is negligible, moreover, the small quantities of micas which might be present do not participate significantly in the possible exchange or fixation of $\mathrm{NH}_{4}{ }^{+}$by $\mathrm{K}^{+}$ions [9]. The finest soil particles are dominantly composed of Kaolinite, goethite and various amounts of other Iron and Aluminium oxides. The crystals are generally covered by coatings, the cations and anions in the soil solution are said not to be in direct contact with the bare clay minerals, but rather with micelles covered by oxides and organic matter [10].

Silicate clay minerals often comprises much of the clay fraction of soils and give the soil their stickiness and plasticity when dry. Clay minerals vary in structure and properties, but all have some permanent negative charge due to imperfections in the crystal structure. As a result of the their negative charge, silicate clay minerals can attract bond cations to their surfaces (adsorption).

Potassium is more permanently held by some clay minerals through a stronger bond mechanism. Since most of the inorganic pollutants from septic tanks are anionic, they are not attracted to clay minerals [11].

\section{Equipments and Apparatus}

\section{Analysis of The Termitarium}

Beakers, $\mathrm{pH}$ meter, volumetric flasks, glass rod, phycnometer, stoppered bottle, weighing balance, desiccators, thermometer, drying ovens, (AAS) - UV, water distillation unit, pipettes, polypylene sample container, analytical balance, refrigerator, hot plate, fume cupboard, glass funnel, filter paper, stopwatch, magnetic stirrer, Erlenmeyer flask.

\section{Reagent Used}

Buffer $\mathrm{pH}$, Distilled water, conc. $\mathrm{HCl}$, conc. $\mathrm{HNO}_{3}$, standard solution of the metals, barium solution, vanadium solution, stock Q.C solution of the metals, $\mathrm{H}_{2} \mathrm{O}_{2}$ solution, aluminum nitrate solution, potassium solution, sodium solution, standard solution of cation, stock Q.C. solution of cation, lanthanium solution, stock potassium solution, stock sodium solution, standard phosphate solution, phenolphthalein indicator, ammonium molybdate reagent, stannous chloride reagent, standard phosphate solution, buffer solutions, barium chloride crystals, potassium chromate indicator solution, standard solution of $\mathrm{AgNO}_{3}$, standard solution of $\mathrm{NaCl}$ and $\mathrm{NaOH}$ solution.

\section{Procedure Determination of Soil pH (ASTM 1999)}

The ASTM D4972 method for soil sediments and sludge was used. 20.0g of the fresh samples of the clay and ant hill were weighed into separate beaker and $20 \mathrm{ml}$ of distilled water was added to the weighed samples. The mixture was stirred thoroughly with a glass rod and allowed to stand for 30 minutes. The electrode was then inserted into the partly settled suspension and the $\mathrm{pH}$ and temperature were recorded after 180 seconds.

\section{Determination of soil Density}

The ASTM D2216-92 Test method for specific gravity of soil was used. The pycnometer was weighed and the mass was recorded as $\mathrm{M}_{\mathrm{b}}$. The pycnometer was then filled to the calibration mark with distilled water. The mass of the pycnometer and the water was weighed and recorded as $\mathrm{M}_{\mathrm{W}}$ as well as the temperature. The soil samples were dried to a constant mass in an oven at $110^{\circ} \mathrm{C}+5^{\circ} \mathrm{C}$ and then cooled in a desiccator. The dried samples were then sieved in a $4.75 \mathrm{~mm}$ sieve. $100 \mathrm{~g}$ of the soil samples were weighed and placed in the clean dry calibrated pycnometer which was then filled above the soil level with distilled water and soaked for 12 hours.

Trapped air in the mixture was removed by boiling gently for 10 minutes and occasionally agitating the pycnometer to assist the removal of air. The heated samples were then cooled to room temperature. The pycnometer was then filled to the mark with distilled water. The mass of the pycnometer filled with the soil and water was measured and recorded as $\mathrm{M}_{\mathrm{d}}$ and the temperature of the mixture was also recorded. The procedure was repeated a second time before the result was accepted. The result was evaluated using the formula,

$$
\begin{aligned}
& \mathrm{P}=\mathrm{G} \text { at } \mathrm{T}_{\mathrm{b}} * 1000 \mathrm{~kg} / \mathrm{m}^{3} \\
& \mathrm{G} \text { at } \mathrm{T}_{\mathrm{b}}=\mathrm{M}_{\mathrm{s}} /\left(\mathrm{M}_{\mathrm{s}}+\mathrm{M}_{\mathrm{W}}-\mathrm{M}_{\mathrm{d}}\right)
\end{aligned}
$$

\section{Determination of Heavy Metals (ASTM 1999/APHA 1998)}

The ASTM D3651 and APHA 3111B standard for testing heavy metals was used. The method involves the preparation of the working standard of the metal. The concentration of the element (iron) was read through the Atomic Adsorption Spectrophotometer (AAS). The wavelength of the metal was selected and the apparatus was standardized with blank which contain no metal. Standard were aspirated and the absorbance was used to 
prepare a calibration curve. The sample was also aspirated, after which the calibration curve was used to determine the concentration of the desired metal.

The concentration was determined by using the formula;

Metal concentration, $\mathrm{mg} / \mathrm{l}=\frac{(\mathrm{A}-\mathrm{B})^{*} \mathrm{C}}{\mathrm{D}}$

\section{Determination of Exchangeable Cations (ASTM 1999/APHA 1998)}

The APHA 3111B and ASTM D 3561 testing procedures was used. The methods were used to evaluate the concentration of $\mathrm{Mg}, \mathrm{Ca}, \mathrm{K}$ and $\mathrm{Al}$. The intermediate and working standard solution were prepared for each exchangeable cation. The calibration curve was then obtained from the Atomic Adsorption Spectrophotometer. The concentrations of the elements were then evaluated using the correlation,

Cation concentration, $\mathrm{mg} / \mathrm{l}=\left(\mathrm{C}_{\mathrm{c}} * \mathrm{Y}\right) / \mathrm{X}$

\section{Determination of Phosphate (CAEM/APHA 1998)}

The APHA 4500-P D testing procedure for phosphate was used. A drop of phenolphthalein indicator was added to $100 \mathrm{ml}$ of the sample which contains $2 \mathrm{mg} / 1$ phosphate. As the sample turned pink, strong acid solution was added drop wisely to discharge the color. $4 \mathrm{ml}$ of molybdate reagent was added to the mixture and allowed to mix thoroughly. 10 drops of stannous chloride solution was added to the sample and allowed to mix thoroughly. The absorbance was measured after 10 minutes at $690 \mathrm{~nm}$ with the $10 \mathrm{~mm}$ cell. The concentration was calculated using the formula,

$\mathrm{PO}_{4}{ }^{3-}, \mathrm{mg} / \mathrm{l}=\underline{\mathrm{mg} \mathrm{P}(\text { in approximately } 104.5 \mathrm{ml} \text { final soln. }) * 1000}$

Sample volume $(\mathrm{ml})$

\section{Determination of Sulphate (APHA 1998/CAEM)}

The APHA $4500 \mathrm{SO}_{4} \mathrm{E}$ testing method was used for analysis. Due to the turbidity of the sample, it was filtered and $100 \mathrm{ml}$ of the sample was measured into a $250 \mathrm{ml}$ Erlenmeyer flask. The mixture was diluted with $100 \mathrm{ml}$ of distilled water. $20 \mathrm{ml}$ of the buffer solution A was added to the mixture and allowed to mix thoroughly in the stirring apparatus. A spoonful of $\mathrm{BaCl}_{2}$ was added as the mixture was being stirred at constant speed for up to a 1 minute. The solution was poured into a $10 \mathrm{~mm}$ cell and the turbidity was measured within 5 minutes at $420 \mathrm{~nm}$. The concentration was evaluated using the formula,

$$
\begin{array}{ll}
\mathrm{SO}_{4}{ }^{2-}, \mathrm{mg} / \mathrm{l}= & \frac{\mathrm{mg} \mathrm{SO}_{4}{ }^{2-*} \cdot 1000}{\text { Sample volume }(\mathrm{ml})}
\end{array}
$$

\section{Determination of Chloride (ASTM 1999/APHA 1998)}

The ASTM D521B (Silver Nitrate titration) and the APHA $4500 \mathrm{Cl}^{-}$B methods were used. The sample was measured into a conical flask and $1.0 \mathrm{ml}$ of potassium chromate indicator solution was added to mix with the sample. $\mathrm{AgNO}_{3}$ standard solution was added drop wisely from a $50 \mathrm{ml}$ burette until the mixture turned brick red. The procedure was repeated with half of the original sample and then diluted to $50 \mathrm{ml}$ with distilled water. The chloride ion concentration in the original sample is evaluated using the formula,

Chloride, $\mathrm{mg} / \mathrm{kg}=\left[\left(\mathrm{V}_{1}-\mathrm{V}_{2}\right) * \mathrm{~N} * 35450\right]$

$$
\text { Aliquot } * \text { weight of sample }
$$

\section{Model Equations}

The modeled equations for some of the activities in the termitarium are as follows:

- For termitarium internal temperature $(\mathrm{K})$ over time (months):

$\left.\mathrm{F}(\mathrm{X})=\mathrm{a}_{1}{ }^{*} \exp \left[\left(\mathrm{X}-\mathrm{b}_{1}\right) / \mathrm{C}_{1}\right)^{2}\right]+\mathrm{a}_{2} * \operatorname{expt}\left[-\left(\left(\mathrm{X}-\mathrm{b}_{2}\right) / \mathrm{C}_{2}\right)^{2}\right]+\mathrm{a}_{3} * \exp \left[-\left(\left(\mathrm{X}-\mathrm{b}_{3}\right) / \mathrm{C}_{3}\right)^{2}\right]$.

Where $a_{1}, a_{2}, a_{3}, b_{1}, b_{2}, b_{3}, c_{1}, c_{2}, c_{3}$, are arbitrary constants.

- For \% water absorbed by control soil over time and

- For \% water absorbed by termitarium over time:

$\mathrm{Y}=\mathrm{W} *(1-\mathrm{wo} * \exp (-\mathrm{K} * \mathrm{X})$

Where W, K and wo are arbitrary constants (16).

- For seedlings on control soil over time:

$\mathrm{F}(\mathrm{X})=\mathrm{P}_{1} * \mathrm{X}^{6}+\mathrm{P}_{2} * \mathrm{X}^{5}+\mathrm{P}_{3} * \mathrm{X}^{4}+\mathrm{P}_{4} * \mathrm{X}^{3}+\mathrm{P}_{5} * \mathrm{X}^{2}+\mathrm{P}_{6} * \mathrm{X}+\mathrm{P}_{7}$

- For seedling on termitarium over time:

$\mathrm{F}(\mathrm{X})=\left(\mathrm{P}_{1} * \mathrm{X}^{2}+\mathrm{P}_{2} * \mathrm{X}+\mathrm{P}_{3}\right) /\left(\mathrm{X}^{3}+\mathrm{q}_{1} * \mathrm{X}+\mathrm{q}_{2} * \mathrm{X}+\mathrm{q}_{3}\right)$

Where $\mathrm{P}_{1}, \mathrm{P}_{2}, \mathrm{P}_{3}, \mathrm{q}_{1}, \mathrm{q}_{2}$, and $\mathrm{q}_{3}$, are arbitrary constants. 
From the above models tables $2 \mathrm{a}-6 \mathrm{a}$ (curled from the work at Amazonia, U.S.A. by Ackerman, I.L. et al., [17] are biomodeled to develop mathematical equations that represent some activities in the making of termitarium as bioengineering system.

Table 2a: A table showing the termitarium's internal temperature (K) and time (month)

\begin{tabular}{|l|l|l|l|l|l|l|l|l|l|l|l|l|l|}
\hline Time (months) & 0 & 1 & 2 & 3 & 4 & 5 & 6 & 7 & 8 & 9 & 10 & 11 & 12 \\
\hline $\begin{array}{l}\text { Temperature } \\
(\mathrm{K})\end{array}$ & 75 & 80 & 50 & 25 & 15 & 10 & 20 & 25 & 40 & 55 & 115 & 80 & 85 \\
\hline
\end{tabular}

Table 3a: A table showing the \% water absorbed by control soil over time

\begin{tabular}{|l|l|l|l|l|l|l|}
\hline Time(s) & 0 & 6.0 & 20 & 40 & 60 & 80 \\
\hline $\begin{array}{l}\text { Water absorbed (g water/g } \\
\text { soil) }\end{array}$ & 0 & 2.10 & 4.30 & 4.45 & 4.45 & 4.45 \\
\hline
\end{tabular}

Table 4a: A table showing the \% water absorbed by termitarium over time(s)

\begin{tabular}{|l|l|l|l|l|l|l|l|}
\hline Time(s) & 0 & 6.0 & 20 & 40 & 60 & 80 & 100 \\
\hline $\begin{array}{l}\text { Water absorbed (g water/g } \\
\text { soil) }\end{array}$ & 0 & 0.5 & 1.0 & 1.45 & 1.6 & 1.75 & 1.8 \\
\hline
\end{tabular}

Table 5a: A table showing the mean number of seedlings over time (days) for control soil

\begin{tabular}{|c|l|l|l|l|l|l|l|l|l|l|}
\hline Time(days) & 0 & 5.0 & 6.4 & 10 & 11.8 & 16.8 & 20 & 23.6 & 30 & 375 \\
\hline Number of seedlings & 0 & 8.5 & 9.5 & 14.5 & 20.5 & 21.0 & 23 & 24 & 20.0 & 15.5 \\
\hline
\end{tabular}

Table 6a: A table showing the mean number of seedlings over time (days) for termitarium

\begin{tabular}{|l|l|l|l|l|l|l|l|}
\hline Time $(\mathrm{s})$ & 5.0 & 6.53 & 10 & 15 & 21.9 & 30 & 38.85 \\
\hline Number of seedlings & 0 & 1.0 & 2.0 & 3.0 & 4.0 & 2.5 & 1.0 \\
\hline
\end{tabular}

\section{Results}

Below is the result of the chemical analysis of termitarium.

Table 1: A table showing the experimental result on termitarium/Clay soil (Control)

\begin{tabular}{|l|l|l|l|}
\hline \multirow{2}{*}{ Parameter } & \multicolumn{2}{c|}{ Results } \\
\cline { 2 - 4 } & $\begin{array}{l}\text { Termitarium } \\
\text { (T) }\end{array}$ & $\begin{array}{l}\text { Clay Soil } \\
\text { (C) }\end{array}$ & $\begin{array}{l}\text { Termite added } \\
\text { (T }- \text { C) }\end{array}$ \\
\hline PH(H $\mathrm{H}_{2} 0$ @ $25^{\circ} \mathrm{C}$ & 6.61 & 6.93 & -0.32 \\
\hline Density $(\mathrm{g} / \mathrm{kg})$ & 1.44 & 1.46 & -0.02 \\
\hline TOM $(\mathrm{g} / \mathrm{kg})$ & 11.60 & 4.50 & 7.1 \\
\hline Phenol $(\mathrm{mg} / \mathrm{kg})$ & 6.24 & 6.95 & -0.71 \\
\hline Calcium $(\mathrm{m} / \mathrm{kg})$ & 51.90 & 109 & -57.1 \\
\hline Magnesium $(\mathrm{mg} / \mathrm{kg})$ & 15.9 & 12.2 & 3.7 \\
\hline Potassium $(\mathrm{mg} / \mathrm{kg})$ & 808 & 1023 & -215 \\
\hline Aluminium $(\mathrm{mg} / \mathrm{kg})$ & 7,104 & 7968 & -864 \\
\hline Iron $(\mathrm{mg} / \mathrm{kg})$ & 11,690 & 7701 & 3989 \\
\hline Extractable Chloride $(\mathrm{mg} / \mathrm{kg})$ & 23.3 & 14.0 & 9.3 \\
\hline Extractable Sulphate $(\mathrm{mg} / \mathrm{kg})$ & 50.0 & 50.0 & 0 \\
\hline $\begin{array}{l}\text { Extractable } \\
\text { (mg/kg) }\end{array}$ & 0.78 & 0.85 & -0.07 \\
\hline
\end{tabular}

\subsection{Model Results}

The following tables contain the values of the models constants (Co-efficient) and statistical data for the curve-fitting of tables $2 \mathrm{a}, 3 \mathrm{a}-6 \mathrm{a}$ to obtain figs. $1-5$.

Table 2b: Plot of table $2 a$ for model $=a_{1} \exp \left[-\left(\left(x-b_{1}\right) / C_{1}\right)^{2}\right]+a_{2} \exp \left[-\left(\left(x-b_{2}\right) / C_{2}\right]+a_{3} \exp \left[-\left(\left(x-b_{3}\right) / C_{3}\right)^{2}\right],(s e e\right.$ Fig. 1)

\begin{tabular}{|l|l|l|l|}
\hline \multicolumn{2}{|c|}{ Co-efficient (95\% Confidence (abound) } & \multicolumn{2}{c|}{ Goodness of fit } \\
\hline $\mathrm{a}_{1}$ & $50.53(35.31,65.75$ & SSE & 32.42 \\
\hline $\mathrm{a}_{2}$ & $89.84(61.73,117.9)$ & R-Square & 0.9975 \\
\hline $\mathrm{a}_{3}$ & $80.8(74.54,87.07)$ & Adjusted R - Square & 0.9925 \\
\hline $\mathrm{b}_{1}$ & $10(9.69,10.32)$ & RMSE & 2.847 \\
\hline $\mathrm{b}_{2}$ & $13.37(9.136,17.59)$ & & \\
\hline $\mathrm{b}_{3}$ & $0.5614(0.2967,0.8262)$ & & \\
\hline $\mathrm{c}_{1}$ & $0.6175(0.2568,0.9781)$ & & \\
\hline $\mathrm{c}_{2}$ & $5.842(2.721,8.8 .964)$ & & \\
\hline $\mathrm{c}_{3}$ & $2.083(1.658,2.507)$ & & \\
\hline
\end{tabular}


Table 3b: Plot of table 3a for model $y=W\left(1-w_{0} \exp (-k x)\right)$, (see Fig. 2)

\begin{tabular}{|l|l|l|l|}
\hline \multicolumn{2}{|c|}{ Co-efficient (95\% Confidence (abound) } & \multicolumn{2}{c|}{ Goodness of fit } \\
\hline $\mathrm{W}$ & $4.511(4.201,4.8210)$ & SSE & 0.08456 \\
\hline $\mathrm{K}$ & $0.1167(0.07512,0.1584)$ & R - Square & 0.9951 \\
\hline $\mathrm{W}_{\mathrm{o}}$ & $1.011(0.8945,1.128)$ & Adjusted R-square & 0.9919 \\
\hline & & RMSE & 0.1679 \\
\hline
\end{tabular}

Table 4b: Plot of table 4a for model $y=W\left(1-w_{0} \exp (-k x)\right)$, (see Fig. $3 \quad$ )

\begin{tabular}{|l|l|l|l|}
\hline \multicolumn{2}{|c|}{ Co-efficient (95\% Confidence (abound) } & \multicolumn{2}{c|}{ Goodness of fit } \\
\hline $\mathrm{W}$ & $1.805(1.674,1.937)$ & SSE & 0.01156 \\
\hline $\mathrm{K}$ & $0.04023(0.02911,0.05135)$ & R - Square & 0.9959 \\
\hline $\mathrm{W}_{\mathrm{o}}$ & $0.9738(.902,1.046)$ & Adjusted R - Square & 0.9939 \\
\hline & & RMSE & 0.05375 \\
\hline
\end{tabular}

Table 5b: Plot of table 5a for model $\mathbf{y}=\mathbf{P}_{1} \mathbf{X}^{6}+\mathbf{P}_{2} \mathbf{X}^{5}+\mathbf{P}_{3} \mathbf{X}^{4}+\mathbf{P}_{4} \mathbf{X}^{3}+\mathbf{P}_{5} \mathbf{X}^{2}+\mathbf{P}_{6} \mathbf{X}+\mathbf{P}_{7}$ (see Fig. 4)

\begin{tabular}{|l|l|l|l|}
\hline \multicolumn{2}{|c|}{ Co-efficient (95\% Confidence (abound) } & \multicolumn{2}{c|}{ Goodness of fit } \\
\hline $\mathrm{P}_{1}$ & $5983 \mathrm{e}-007,(-3.049, \mathrm{e}-006,4.245 \mathrm{e}-006)$ & SSE & 10.23 \\
\hline $\mathrm{P}_{2}$ & $-6.539 \mathrm{e}-005,(0.0004572,0.0003264)$ & R-Square & 0.9807 \\
\hline $\mathrm{P}_{3}$ & $0.002727(-0.01303,0.01348)$ & Adjusted R - Square & 0.9421 \\
\hline $\mathrm{P}_{4}$ & $-0.05416(-0.3475,0.2392)$ & RMSE & 1.846 \\
\hline $\mathrm{P}_{5}$ & $0.4656(-2.04,2.971)$ & & \\
\hline $\mathrm{P}_{6}$ & $0.2341(-7.732,8.2)$ & & \\
\hline $\mathrm{P}_{7}$ & $0.06145(-5.812,5.935)$ & & \\
\hline
\end{tabular}

Table 6b: Plot of table 6a Model $y=\left(P_{1} X^{2}+P_{2} X+P_{3}\right) /\left(X^{3}+q_{1} X^{2}+q_{2} X+q_{3}\right)$, (See Fig. 5)

\begin{tabular}{|l|l|l|l|}
\hline \multicolumn{2}{|c|}{ Co-efficient (95\% Confidence (abound) } & \multicolumn{2}{c|}{ Goodness of fit } \\
\hline $\mathrm{P}_{1}$ & $-12.17(-7788,53.54)$ & SSE & 0.005739 \\
\hline $\mathrm{P}_{2}$ & $948.6(-1638,3536)$ & R-Square & 0.9995 \\
\hline $\mathrm{P}_{3}$ & $-4441(-1576 \mathrm{e}+004,6874)$ & Adjusted R - Square & 0.9969 \\
\hline $\mathrm{q}_{1}$ & $-48.96(-66.67,31.25)$ & RMSE & 0.07575 \\
\hline $\mathrm{q}_{2}$ & $819.6(298.9,340)$ & & \\
\hline $\mathrm{q}_{3}$ & $-2335(-5817,1147)$ & & \\
\hline
\end{tabular}

\section{Discussion}

From the results in the table 1, both samples of ordinary clay and termitarium contain somewhat the same physical and chemical composition but in varying amounts.

Although both soils were slightly acidic, the $\mathrm{pH}$ value was lesser in termitarium soil than in control soil. Total Organic Matter (TOM) content was about twice in termitarium. There was no significant difference in their densities. Also, there was a slight but significant decrease of phenol in termitarium soil than the control soil.

The level of exchangeable $\mathrm{Ca}, \mathrm{K}$ and $\mathrm{Al}$, were greater in control soil, with about twice the amount of $\mathrm{Ca}$ in the control soil. Conversely, the concentration of $\mathrm{Mg}$ was greater in termitarium soil than in the control soil.

The termitarium soil was highly enriched in Iron as compared with the control soil. There was a slight but significant increase of extractable phosphate. The extractable chloride is very significantly greater in termitarium soil than in the control soil.

Infact, the last column in table $1,(\mathrm{~T}-\mathrm{C})$ shows the amount of chemical the termites added to or removed from the termitarium during the mould-making by way of secretion, faeces and other activities. $115^{\circ} \mathrm{K}$.

From the result of the modeling, termitarium soil (Fig. 1) has optimum calcinations temperature at

Time to saturation differed significantly between the termitarium and control soil (tables 3a and 4a). The time to saturation was $80 \%$ greater for termitarium soil (Fig. 3) than control soil (Fig. 2). The number of seeds germinating was $78 \%$ lower in the termitarium (Fig. 5) than in control soil (Fig. 4).

\section{Conclusion}

Termitarium from this study was seen to contain numerous chemicals among which are magnesium, Iron, Extractable chloride and TOM, and were discovered to be responsible for its unique tensile properties. 
Although both samples (clay/termitarium) taken for analysis contain the same physical and chemical compositions in different amount.

The study also showed that the total organic matter (TOM) is responsible for binding the larger particles of the termitarium together. The exchangeable Cation (EC) such as magnesium was also noted to enhance the cohesive force between the particles and thus the stability of the aggregates [18].

The results from modeling proved that termitarium has high water retention properties with an exponential graph. The results also indicated that termitarium soil hardly favour seeds germination due to its hard nature.

\section{Recommendation}

The rising issue of alternative source of building materials could be addressed through a closer look at the termitarium.

It is worthy to note that each clay has an optimum calcinations temperature range that causes breakdown when in use, therefore, it is advisable that house builders should resort to the use of clay in place of cement, noting its optimum temperature for greater efficiency. Potters as well as pipeline constructors are encouraged to make an extensive use of clay material in their sculptural works for the sake of quality and cheapness and of course pollution free.

In the agricultural sector, farmers are advised to avoid planting crops on land that is largely occupied by termitarium as seeds germination are grossly hindered as a result of high water retention properties and tensile strength.

\section{$\mathrm{p} \quad$ density of the soil sample}

\section{Nomenclature}

$\mathrm{T}_{\mathrm{b}} \quad$ temp. of the content of the pycnometer

$\mathrm{M}_{\mathrm{s}} \quad$ mass of oven dried soil sample, $\mathrm{g}$

$M_{w} \quad$ mass of pycnometer with water at temp. $T_{b}, g$

$\mathrm{M}_{\mathrm{d}}$ mass of pycnometer filled with soil and water.

A conc. Of metal in sample, $\mathrm{mg} / \mathrm{l}$

B conc. Of metal found in blank, $\mathrm{mg} / \mathrm{l}$

C Vol. of extract, $\mathrm{ml}$

D Vol. of sample, $\mathrm{ml}$

$\mathrm{C}_{\mathrm{c}} \quad$ conc. of cation from the calibration curve, $\mathrm{mg} / \mathrm{l}$

$\mathrm{Y}$ final vol. make up, $\mathrm{ml}$

$\mathrm{X} \quad$ Vol. of sample, $\mathrm{ml}$

$\mathrm{V}_{1} \quad$ Standard soln of $\mathrm{AgNO}_{3}$ added in the first titration

$\mathrm{V}_{2}$ Standard soln of $\mathrm{AgNO}_{3}$ added in the second titration

$\mathrm{N} \quad$ Normality of standard $\mathrm{AgNO}_{3}$ solution

SSS Sum of square error

RMSE Root mean square error

$\mathrm{NaN} \quad$ Not a number

$\mathrm{R}^{2} \quad$ Coef. Of correlation

\section{References}

[1]. Eggleton, P ., Homathevi , R ., Jones, D . T ., MacDonald , J . A ., Jeeva , D .,

[2]. Bignell , D . E ., Davies, R . G . \& Maryati, M . ( 1999 ) Termite assemblages, forest disturbance and greenhouse gas fl ux es in Sabah, EastMalaysia . Philosophical Transactions of the Royal Society of LondonSeries B-Biological Sciences, 354, $1791-1802$.

[3]. Gehring, C., Denich, M., Kanashiro, M. and Vlek, P.L. G. (1999), Response of Secondary Vegetation in Eastern Amazonia to relaxed nutrient availability constraints. Biogeochemistry 45 (3), $223-241$.

[4]. Adepegba, D., Adegijem E.A. (1974). A study of the compressive Strength and Stabilizing Chemicals of Termite mound in Nigeria. Soil Sci. 117 (3) $175-179$.

[5]. Donovan et al (2001). Effect of termites on clay minerals in tropical soils. Fungus- growing termites as weathering agents. Eur. J. Soil Sci. 53: $521-527$.

[6]. Jouquet, P., Lepage, M. and Velde, B. (2002). Termite Soil preference and particle selections: strategies related to ecology requirement. His. Soc. 49 ( 1 - 7)

[7]. Mora, P. , Seuge, C., Chotte, J. L. and Rouland, C. (2003). Physics-chemical typology of the biogenic structure of termites and earthworms: a comparative analysis. 37: $245-249$

[8]. Brady, N. C. and Weli, R. R. (1999). Soil Erosion and its control, $12^{\text {th }}$ ed., the nature and properties of Soils, Prentice Hall, pp. 668 -722 ).

[9]. Holt, J.A. and Leapge, M. (2000). Termites and soil properties, In: Abe, T., Bignell, D. E.; termites. Evolution, sociality, Symbioses, Ecology, Kluwer Academic Publishers, Dordrecht, The Netherlands, pp. 389 - 408.

[10]. William, L. Luyben (1989). Process Modeling Simulation and Control, $2^{\text {nd }}$ Ed. 4: $13-18$.

[11]. Anderson, S. J and Sponsito, G. (1992). Proton surface charge density with structural and pH-dependent charge, soil sci. soc. Am J. $56,1437-1443$. 
[12]. Snyder, T.E. (1949). Catalogue of the termites (Isoptera) of the world Smiths. Inst. Mise Coll. 112 (3953) $1-490$.

[13]. Velde, B. (1995). Origin and Mineralogy of clays: clays and the environment Spinger verlag. Berlin Iherdelberg New York.

[14]. Ebeling, W. (1968). Termites, Identification, biology and control of termites attacking building.

[15]. Strud, K. A. and Booth, D. J. (2001). Engineering Mathermatics, Palgrave, $5^{\text {th }}$ edition, Houndmills, Basingstoke, Hampshire RG21 6xs, pp. $709-746$.

[16]. Ackerman, I.L., Teixeira, W.G., Riha, S.J., Lehmann J. and Fermandes, E.C.M. (2007). The impact of mound-building termites on surface soil properties in a secondary forest of Central Amazonia, Applied Soil Ecology, 37 (2007) 267 - 276.

[17]. Tessier, D., Lahudie, A. and Petit, J. C. (1992). Relation between the macroscopeic behavior of clays and their micro structural properties Appl. Geochem. 1 151-161.

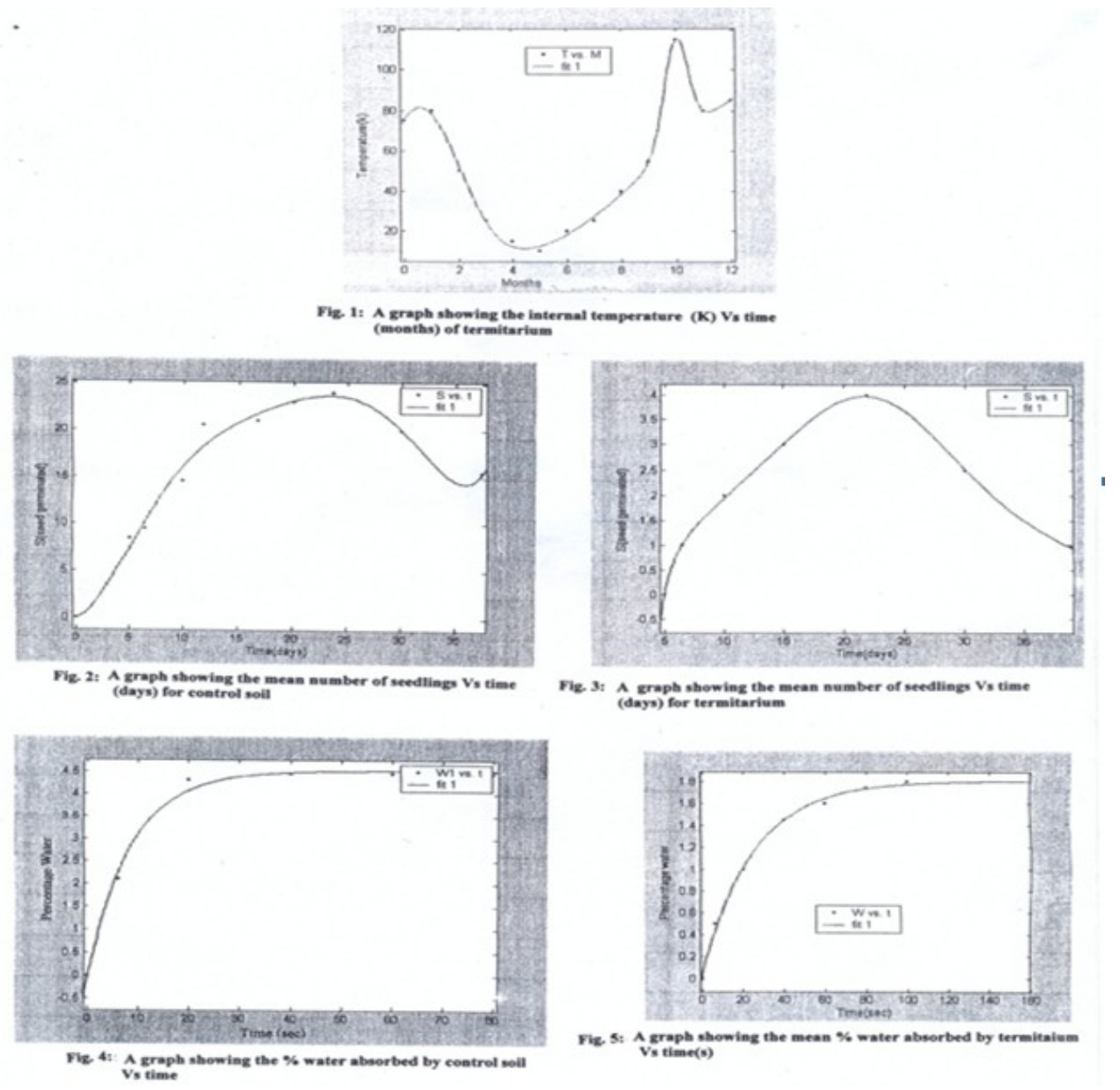

